\title{
Study on Law Violations Concerning Facility Agricultural Land in Yunnan Province
}

\author{
Ma Qiongli \\ School of Finance and Public Management, \\ Yunnan University of Finance and Economics, Kunming, Yunnan, China
}

1040086919@qq.com

\begin{abstract}
The thesis is from the study on agricultural land law violation and governance practice implemented in Yunnan Province funded by Yunnan Provincial Department of Land and Resources, which the author is responsible for independently. The thesis mainly studies the facility agricultural land law violations, causes and governance measures of Yunnan Province by field research. The study is of certain practical significance for Yunnan Province to restrain unlawful acts concerning facility agricultural land and promote healthy development of agricultural industrialization in Yunnan.
\end{abstract}

Keywords-Yunnan Province; Facility Agricultural Land; Law Violation

\section{CURRENT Status ABout Law Violation OF}

\section{FACILITy Agricultural LAND IN YunNAN Province}

Based on colorful natural resources and ecological environment advantages of the low latitude plateau and focused on the strategic goal of "building a powerful green economic province", Yunnan Province starts the provincial agricultural modernization construction from alpine feature agriculture, follows the thought of building Yunnan into the "one teemed with rice, vegetables, fruits, tea, flowers, meat, fish and medicine" important in China, and pays every endeavors to build alpine feature agriculture into the new engine for provincial economic growth. At present Yunnan alpine feature agriculture together with massive agriculture in northeast China, intensive agriculture in Zhejiang and Jiangsu and urban agriculture in Beijing, Tianjin and Shanghai become four typical zone modes in modern agricultural development in China, and Yunnan alpine feature agriculture has made remarkable contributions to socioeconomic development in Yunnan. However, in the meantime, the facility agriculture, which is the important content and centralized embodiment in Yunnan agricultural modernization and industrialization, has many problems concerning land use, such as backward systems, absence of planning, inefficient management, and growing law violations, and illegal facility agricultural land becomes the new representative and tending land type of law violations in the province. Land and resources law enforcement authorities at all levels in Yunnan Province have reinforced law enforcement in facility agricultural land, and accomplished remarkable results since 2013. As the root cause for these violations is not the law enforcement, the law violations concerning facility agricultural land take place frequently and easily in Yunnan Province, and the situation is not changed substantially, and law enforcement still faces enormous pressure. Yunnan Province should attach much importance to it to find the causes for law violations concerning facility agricultural land and put an end to the law violation trends, which is also an important issue for long-term development of economic society. 


\section{ANALYSIS OF CAUSES FOR LAW}

\section{VIOLATIONS CONCERNING FACILITY AGRICULTURAL LAND}

\section{IN YUNNAN PROVINCE.}

Firstly the unbalanced land supply. Yunnan is a province featured in "mountains, ethnic groups, border and poverty". The province is still underdeveloped in China with insufficient, uncoordinated, unbalanced and unsustainable development. Yunnan has unbalanced distribution of land resources, distinctive difference in land use, and a large amount of arable land but poor quality. The basic farming land protection ratio is large, wasteland suitable for development is not much, the reserved land resources are limited, and the conflicts between resources and environment are striking.

Secondly backward legal construction. The legal construction concerning facility agricultural land falling behind of practical economic society development is the core cause for quite many facility agricultural land and law enforcement barriers. Since the end of the 20th century, the modern agriculture in China has ushered in the rapid development, and the facility agriculture has kept developing. However, the state fails to develop legal system building concerning facility agricultural land, and this is seriously unaligned with the agricultural modernization development trend, one of contemporary China's core national strategies. In early 21st century, the Ministry of Agriculture and the Ministry of Land and Resources prepared the documents to support facility agricultural development and regulate facility agricultural land administration. However, due to legal hierarchy and inadequate experience, the documents have many defects, such as inadequate authority, vague stipulations and unable to meet realistic needs.

Thirdly, local economic benefit drive. The land administration laws and regulations in force in China are focused on land purpose control, and they highlight on the use of construction land and protection of farming land. According to the strictest arable land protection system, the facility agricultural land administration is very "strict". However, when the land use indexes are in shortage, arable land protection tasks are heavy, and economic development pressure is huge, some governments know well that modern agricultural production and operation mode with the mix of the primary, secondary and tertiary industries is the economic development highlight with the new commercial activities, so out of concerns for local interests, they have loose, weak and mild regulation for facility agricultural land to reap benefits in terms of taxation, employment, GDP, etc. Some local governments acquiesce in and wink at the constructors to carry out nonagricultural construction of investment promotion and key projects in the name of facility agriculture, or expand land area for nonagricultural construction without authorization, and the supervision is loose and absent.

Fourthly low risks and small costs for law violations. "Land Administration Law" in force of China has light punishments on unlawful acts, which are not aligned with national situations, economic development levels and "three-strictest" national land policies. Meanwhile, Yunnan is a border province with many ethnic groups, and some farmers and people of ethnic groups have weak legal consciousness. They think it's their right to carry out facility agricultural construction on their native land. Local governments are in vain to stop law violations, and they turn blind to unlawful acts so as to safeguard national unity, keep social stability, safeguard rights and interests of farmers, etc. When other farmers see no punishment following law violations, they have the same illegal acts, so the vicious circle results in more violations and no punishment on numerous offenders.

Fifthly extensive regulation ways. Yunnan Province has quite extensive regulation ways for facility agricultural land administration, which is not synchronous with the facility agriculture. Intensive law enforcement is impossible based on such administration. Yunnan Province does not prepare special planning for facility agricultural land, and operators are enthusiastic to apply for facility agricultural land during recent years. however, as the planning control and guidance is absent, the spatial layout of facility agricultural land is quite 
random, facility agricultural land is everywhere not in clusters, and the law enforcement is increasingly difficult. Scientific facility agricultural land special planning is in favor of concentrated facility agricultural land, it avoids occupation of quality arable land, and improves the use ration of unused and idle land, such as barren mountains and slope and shoals. When there are increasingly law violations concerning facility agricultural land, the county level land departments and township land offices still turn a blind eye to these violations.

\section{RECOMMENDED POLICIES FOR GOVERNANCE OF LAW}

\section{VIOLATIONS CONCERNING FACILITY AGRICULTURAL LAND}

\section{IN YUNNAN PROVINCE}

Firstly formulate local laws and regulations on facility agricultural land administration of Yunnan Province. It needs a long time for the state to establish a complete national legal system. Therefore, targeting at socioeconomic development, agricultural modernization a nd arable land protection of Yunnan Province, prepare provincial level local arable land protection regulations "Yunnan Province Arable Land Protection Regulations" or local government rules "Yunnan Province Arable Land Protection Measures", in which a chapter to regulate facility agricultural land use, administration, supervision and law enforcement will be provided. Only laws or regulations may effectively define facility agriculture standards, facility agriculture project access threshold, facility agricultural land scope, quality standards, three-dimensional space, use terms of facility agricultural land, so as to effectively define administration, supervision and law enforcement power and liability allocation and adjustment of governments at all levels and governmental sectors, and provide substantial stipulations concerning facility agricultural land law enforcement rights, ways, reward \& punishment, etc.

Secondly define the facility agricultural land scope scientifically based on the provincial circumstances. As for universal and homogeneous facility agricultural projects within the national scope, they are universal nationwide, so vague principle will apply; the facility agricultural project within the alpine feature agriculture scope in Yunnan has special and heterogeneous features in terms of agricultural production, external manifestation, auxiliary and supporting facility land needs, etc., and the production, auxiliary and supporting facility land scope should be defined in line with the explicit principles. The alpine feature agricultural industries, which need to be defined in the facility agricultural land scope with regard to Yunnan Province alpine geographical features and land resources characteristics, include rubber, coffee, flowers, sugarcane, tea, silkworm, potato, live pig, cattle \& sheep, vegetable, flower seedlings, traditional Chinese medicine, walnut, fruits, edible mushroom, etc.

Thirdly formulate facility agricultural land planning. As per facility agricultural land development needs, formulate Yunnan Province facility agricultural development planning with regard to environmental protection, hygiene and disease control, regional landform characteristics, etc. Based on the mutual link and overall plans, promote the coordinated development between facility agricultural land development and urbanization and land resources use unanimously, and arrange the scale and layout for various facility agricultural land in each area. Follow the principle of arable land protection and strict scale control, take measures such as total amount control, reasonable layout, structure and index regulating, occupy no or little arable land for facility agricultural land construction, strictly control ancillary and supporting facility land, highlight on tapping potential of facility agricultural land and flexibly using available land, and guide some facility agriculture towards high-altitude and underground space development. Conform to the ecological priority and optimized layout principles, focus on protecting and improving agricultural ecological environment, develop modern ecological agriculture, competitive agriculture and leisure agriculture, optimize facility agricultural land layout, and exert the function effects. Comply with the principle of adjusting measures to local conditions and intensifying regional features, attach much importance 
to regional natural environment's endowment and overall socioeconomic development levels, decide representative facility agriculture, and facilitate further development of modern alpine agricultural industry types and modes with regional features.

Fourthly strengthen law enforcement concerning facility agricultural land. Strictly regulate unlawful facility agricultural land data monitoring and statistics, and force local governments at all levels to underscore prevention, reporting and handling of unlawful facility agricultural land. Get the facility agricultural land violations involved in integrated vacant land law enforcement comprehensive monitoring platform of Yunnan Province, and realize real-time monitoring of various facility agricultural land violations, law enforcement, rectification and fulfillment. List the facility agricultural land violations as the key in routine land law enforcement patrolling and the necessary item in law enforcement standing book records, and highlight on the function of national land offices at the township level to discover and report law

\section{REFERENCES}

[1] Sui Lianfeng. On Shortcomings and Solutions of Land Management in China [J]. Heilongjiang Science and Technology Information, 2016,02:273.

[2] De CHEN, Dongmei XIANG, Shengping SHI, Economic Analysis on Protection of Farmers' Benefits Based on Market of Agricultural Means of Production and Agricultural Products [J]. Asian Agricultural Research, 2013 (11).

[3] Wang Wei-lin, "The Study of Illegal Land Use to Economy Growth" , Chinese Agricultural Science Bulletin, Vol. 26, No. 18, 2010, pp. 438-442. violations on time. In annual routine land law enforcement file evaluation, evaluate a certain proportion of facility agricultural land violation files, and grasp the standardization at the grassroots level to look into unlawful facility agricultural land acts. The provincial level national land resources departments notify facility agricultural land violations and law enforcement for general information on an importance to facility agricultural land law enforcement. Carry out facility agricultural land law enforcement examination regularly to promote the law enforcement. Strictly and severely look into major and typical cases about facility agricultural land violations, make the investigation and punishment results known to the public, and contain the growing trend of facility agricultural land violations resolutely.

\section{ACKNOWLEDGEMENTS}

Support for the study from School of Finance and Public Management, Yunnan University of Finance and Economics and Yunnan Provincial Department of Land and Resources is highly appreciated.

[4] CHEN Zhu, ZHANG An-lu, "Research on Coordination of Farmland Protection Among Eastern, Middle, and Western Regions of China: Flaws of Land Use Efficiency Theory", China Land Science, Vol. 24, No. 4, 2010, pp. 13-18.

[5]CAO Xiao-juan, “Governance to Illegal Activities of Local Government in Land Use and System Creation” , Journal of China University of Geosciences (Social Sciences Edition, Vol. 9, No. 2, 2009, pp. 53-57. 